To appear in International Handbook of Family Policy: A Life-Course Perspective, edited by Mary Daly, Neil Gilbert, Birgit Pfau-Effinge, and Douglas Besharov (Oxford University Press).

\title{
Family Change in the Context of Social Changes in the U.S.
}

Nicholas H. Wolfinger, University of Utah

"If you look back on the Sixties and think there was more good than bad, you're probably a Democrat. If you think there was more harm than good, you're probably a Republican."

-- Bill Clinton, speaking at the 2004 BookExpo

In 1962, two graduate school dropouts named Michael Murphy and Dick Price founded the Esalen Institute on a remote tract of land about 150 miles south of San Francisco. Murphy and Price had drifted into the orbit of many of the day's counterculture thinkers, including Aldous Huxley, Ken Kesey, and Allen Ginsberg, and were captivated by the notion of extending learning beyond what they considered the hidebound constraints of the American educational system. Esalen soon came to offer a full program of hippie-era self-actualization, including encounter groups, transcendental meditation, gestalt awareness training, and guided acid trips.

Within ten years, Esalen's reach went national. A satellite campus in San Francisco was mobbed upon opening, while nearly 100 unaffiliated centers modeling themselves on Esalen had appeared across the country (Storr 2018). In time, outposts cropped up as far away as Switzerland and Bali. Inside those hidebound universities, tuned-in professors and their students were taking Esalen ideas seriously, and they slowly seeped into the broader culture. "Essentially everything that became known by the 1970s as New Age was invented, developed, or popularized at the Esalen Institute," observes Kurt Andersen $(2017,178)$ in his quincentenary history of America. Esalen, continues Andersen, had perfected a new form of American religion, an inward-looking spiritual ontology for people inclined to reject traditional Abrahamic faith and practice. Esalen wasn't the root cause of America's hitherto unknown embrace of solipsism (cf. Lilla 2018), but was at the right place at the right time to incubate and disseminate our strange new civil religion.

By the 1970s, scholars had dissected the Esalen ethos (Lasch 1979; Turner 1976) and had given it a name: expressive individualism. At its most fundamental level, it marked a shift from Americans' orientation from social institutions - governments, organized religion, community organizations, marriage - to individualism. People started saying things like "follow your heart" and "be true to yourself," while casting a jaundiced eye on tradition, received wisdom, and anything else that might interfere with life, liberty, and the pursuit of happiness. The longoverdue civil rights movements of the 1960s dovetailed with expressive individualism by highlighting equality as a paramount value.

Most of all, Americans for the first time saw personal fulfillment as a worthy goal in and of itself. In the 1960s, almost 90 percent of college freshmen deemed "developing a meaningful philosophy of life" to be a very important or essential personal goal (Pryor et al. 2007; see also Twenge, Campbell, and Freeman 2012). As a 50-something Generation Xer writing this chapter 
in 2020, I'm not sure whether I even have a philosophy of life, meaningful or otherwise; as a faculty member at a large state university, I question whether my students even know what a "meaningful philosophy of life" is.

A year before the founding of Esalen, a Chicago-based pharmaceutical company named G.D. Searle and Company began to market a relatively new drug called Enovid. From the beginning it was a controversial product. Access for married women wasn't secured until a 1965 Supreme Court ruling. It wasn't until seven years later that a second Supreme Court decision ensured access to Enovid and subsequent birth control pills for all American women. These years also witnessed the proliferation of another new birth control technology, the intrauterine device.

This chapter describes how expressive individualism and effective contraception launched the revolution that has reshaped the American family since the 1960s. But they didn't do it alone: starting in the 1970s, powerful economic forces exacerbated the changes already underway.

\section{Partisan Differences in Explanations of Family Change}

Like so much of America, explanations for the transformation in American family life have become highly polarized. Conservatives are inclined to attribute the changing American family entirely to cultural trends - the customary academic shorthand for expressive individualism and the sexual revolution - with an assist from the welfare state. They are right to highlight the importance of expressive individualism, but wrong to discount the importance of economic factors. In turn, liberals are correct to highlight how the changing American economy has roiled family life, but often give cultural changes short shrift (Patterson 2014). Cultural upheaval in conjunction with economic change combined to create what W. Bradford Wilcox and I recently called the perfect storm for the American family (Wilcox and Wolfinger 2016, 12).

It's easy to make a strong prima facie case for why both cultural and structural forces have reshaped marriage and childrearing, the primary institutions of the American family. The family started changing in the mid 1960s, years before the economic tumult of the 1970s upended several decades of sustained economic growth. The structural effects are apparent in the modern class divide in marriage. As recently as 1982, more people without four-year college degrees were married than were college graduates; up to that point, the numbers had always been pretty similar. But since then, a large divide has emerged. If you have a four-year college degree, you're likely to get married and stay married. If you don't, marriage is much less likely. Both structural and cultural forces, then, are required to explain modern family demography.

\section{How the 1960s and 1970s Launched Family Change}

Arguably no decade in American history saw more social upheaval than the 1960s. By the time of the Students for a Democratic Society's famed Port Huron Declaration in 1962, some Americans had began chafing against what they perceived as the cookie-cutter conformity of the previous decade. The long arc of the moral universe finally culminated in legal equality for nonwhite Americans, and between the sexes. In the following years would come a heretofore unknown loss of faith in public institutions as America was roiled by assassinations, Vietnam, riots, crime, and, a few years later, Watergate. Prior to Vietnam and Watergate, a majority of 
Americans trusted the federal government. Except for a brief moment after 9/11, that trust never again reached 50 percent (Vavreck 2015; Pew Research Center 2019). Faith in other social institutions declined apace with loss of faith in government. (e.g., Putnam 2000). And as the United States shuddered during the annus horribilis of 1968, so went the rest of the developed world (T. Brown 2013, 2014).

Expressive individualism and landmark progress on civil rights started to transform America in ways that would prove consequential for the American family. In 1962, Helen Gurley Brown's bestseller Sex and the Single Girl introduced the then-radical notion that unmarried women might go out and have sex for pleasure. Even more influential was Betty Friedan's The Feminine Mystique, published a year later. Friedan's book gave voice to women who weren't finding satisfaction in connubial housewifery. Women's labor force participation, already rising, continued to increase (Toosi and Morisi 2017).

Of course the vast majority of Americans didn't drop out, tune in, and turn on. A 1971 poll asked female respondents how often they felt that "being a woman has prevented me from doing some of the things I had hoped to do in life." Only 7 percent said "frequently"; 12 percent said "occasionally"; 79 percent said "hardly ever" (Caldwell 2020, 42-43). Instead, the 1960s touched off a quiet revolution, in which some men and women questioned the 190s ideal of heterosexual marriage, parenthood, a sole-provider husband, and a housewife. Some young women chose to prioritize careers over marriage. Here is what one woman recalled for The New York Times in 2020, decades after reading the Feminine Mystique:

When I was in college in 1965, a friend gave me a copy of "The Feminine Mystique," by Betty Friedan. As a young girl growing up in the 1950s, I was of two minds: On the one hand, I loved school, especially math, loved competing in sports, wanted to make something of myself. On the other hand, I also fantasized about the romantic stories from books and movies and women's magazines of love and marriage and homemaking. As a student at a women's college, I was only just beginning to realize how much in conflict those two futures were. The book laid it all out for me, put into words what I had only sensed.

Meanwhile, women poised to start a family in the mid 1960s received a demographic nudge from the marriage squeeze that originated in the demobilization after World War II (Akers 1967). From 1945 to 1946 the American birth rate shot up from 20.4 births per thousand population to 24.1, almost a 20 percent increase (Centers for Disease Control and Prevention / National Center for Health Statistics 2003). The Baby Boom had begun, and birth rates wouldn't dip to 1945 levels for another 20 years.

The sting was in the tail for heterosexual women born in the first couple of years of the Baby Boom. They started attaining their majority in 1964, eighteen years after the Boom began, but quickly encountered a vexing marriage market. At that time, the median difference in marriage age was two and a half years, so women born at the beginning of the Boom would naturally look to date men born in 1943 and 1944 (United States Census Bureau 2019). But the men weren't there, because birthrates in those years were much lower than then were in the Baby Boom a couple of years later. A profoundly unfavorable marriage market thus ensued for women in the 
mid 1960s. Most of them did eventually get married sometime down the line, but for a small number marriage delayed was marriage foregone. These women would naturally be more receptive to the words of Betty Friedan, Helen Gurley Brown, and other second wave feminists of the era.

The marriage squeeze didn't relegate young women to chastity. After all, it occurred at precisely the same moment when effective contraception was available for the first time, and there was burgeoning acceptability of having sex out of wedlock. Indeed, Americans' sexual behavior permanently changed starting with the cohort that came of age in the 1960s. The median woman born before 1940 had one median lifetime sex partner (Wolfinger 2018). This rose to two for women born in the 1940s, and three for successive decades. The increase for men was even greater. The medians are smaller for the 1980s and 1990s in part because these survey respondents are younger, and may have more sex partners in the years to come.

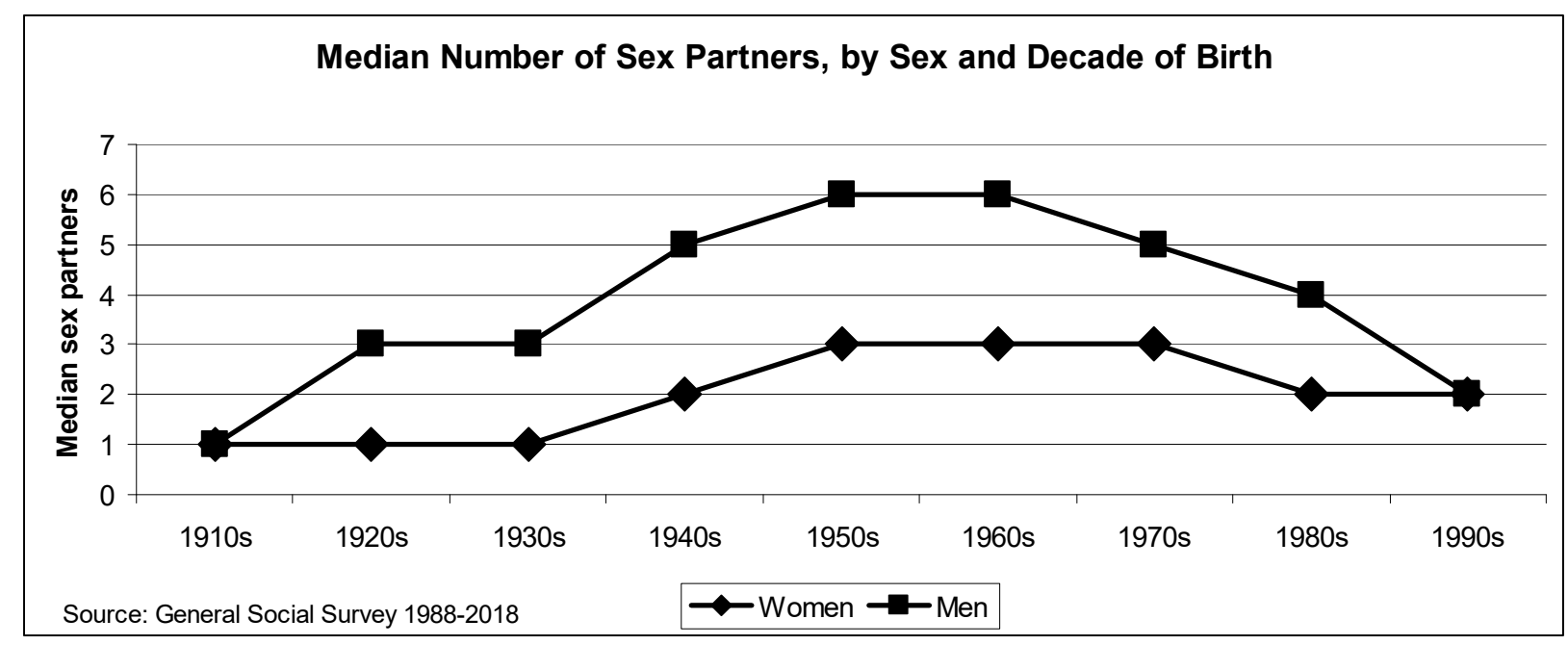

In the mid 1960s, the divorce rate started rising at an unprecedented pace. Divorce rates have always trended upwards over the past few hundred years, but the years between the mid 1960s and 1980 saw the greatest sustained increase in divorce ever recorded (Phillips 1988, 1991). Expressive individualism was the root cause as the Divorce Boom got underway, and people recognized a newfound ideal of being happy in their marriages. There were far fewer reasons to stay in unfulfilling or rancorous unions. To be sure, this fulfilled a vital need. Here's what I wrote in my 2005 book Understanding the Divorce Cycle:

[Prior to the Divorce Boom] couples often waited until their marriages had completely deteriorated before seeking a divorce. Normative expectations persuaded quarreling couples to "stick it out" under circumstances such as domestic violence that would today be readily recognized as reasonable grounds for divorce. When couples finally ended their marriages, the situation may have deteriorated far more than is typical in most divorces today (Wolfinger 2005, 80).

The Divorce Boom turned out to be a mixed blessing. Social scientists would eventually come to identify numerous adverse consequences of divorce, but at the same time it was a positive 
development that parents and children need no longer be trapped in destructive marriages (e.g. Amato, Loomis, and Booth 1995; Jekielek 1998).

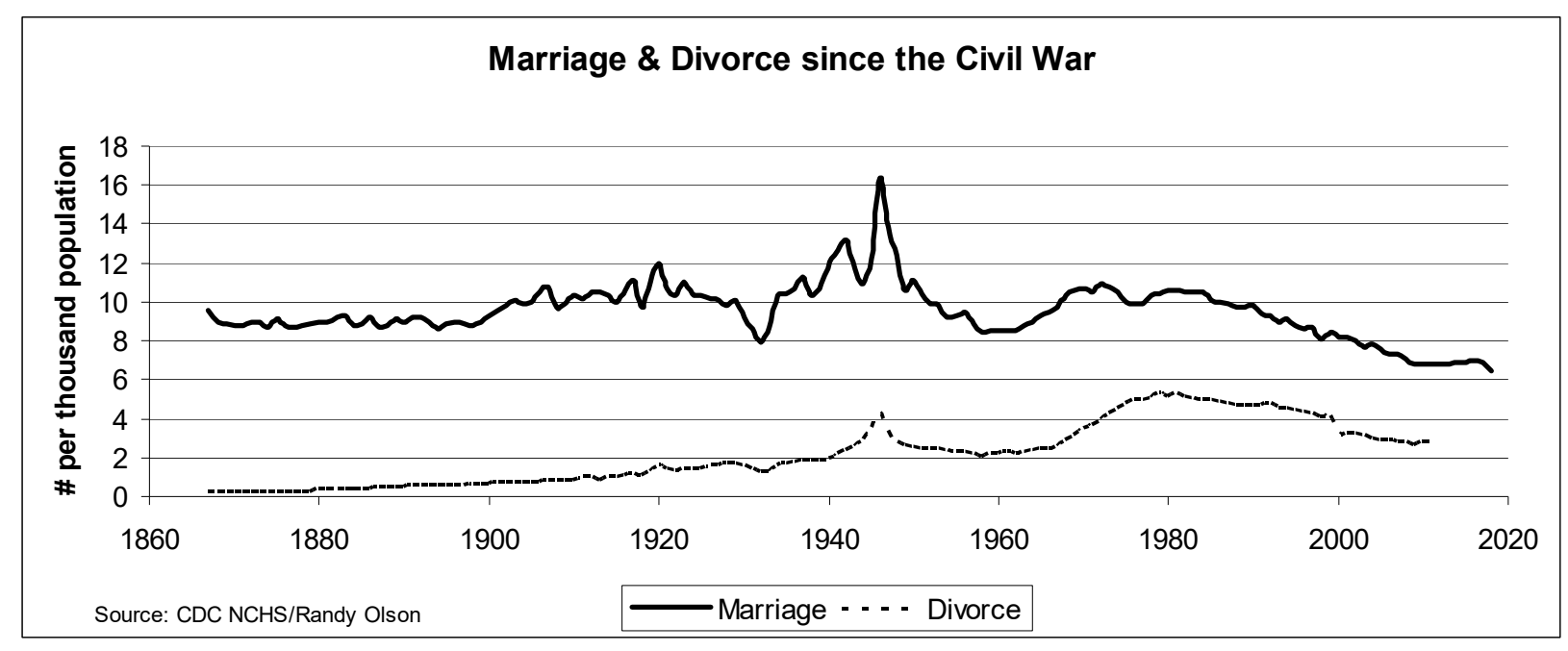

Here's one thing that did not cause the Divorce Boom: the adoption of no-fault laws. California governor Ronald Reagan signed the first modern no-fault law on January 1, 1970 precisely because divorce cases - often involving perjurious allegations of non-existent adultery - were clogging the courts in his state (Wolfinger 2005; see also Vlosky and Monroe 2002; Wernick 1996). How do we know the move to no-fault didn't raise the divorce rate? The divorce rate was already rising in states that adopted no-fault laws early, in the first few years of the 1970s. Afterwards divorce rates continued to rise at the same rate. In contrast, divorce rates were already falling in states that adopted no-fault laws late, in the 1980s. After their adoption divorce rates continued to fall. These trends were documented by the late sociologist Norval Glenn, who was no fan of easy divorce laws (Glenn 1997; see also Wolfers 2006; for a contrary finding, Gruber 2004).

Expressive individualism launched the Divorce Boom. For the first time, large numbers of people got divorced because they were unhappy in their relationships. In due time divorce came to beget more divorce. The presence of other divorced adults legitimized the decision to end a marriage. More broadly, divorce is contagious: people are more likely to divorce when they know more divorced people (Aberg 2011; McDermott, Fowler, and Christakis 2013). Your fellow divorcées may plant the seeds of marital doubt, provide practical advice about single life, and more broadly legitimatize divorce as a solution to a troubled or unfulfilling marriage. Perhaps this is why divorce rates continued to rise for about fifteen years, up until about 1980. Over these same years Americans' attitudes on divorce softened (Phillips 1991; Thornton and Young-DeMarco 2001), and popular culture came to valorize divorce with an enthusiasm that seems bizarre in modern times (Frum 2008). Once the Divorce Boom started, it quickly picked up momentum.

The boom was in full swing by the time the oil shocks and stagflation of the 1970s rolled around. Men's real wages peaked in 1973, capping off decades of expansion. They've rebounded a bit since their nadir, but remain below the 1973 high (Desilver 2018). This broad trend conceals 
large and growing income polarization: wages for college-educated workers have grown, while for everyone else they've declined (Donovan and Bradley 2019).

This trend has had profound differences for the composition of the American family. The steady rise in women's employment was nothing new-it's been increasing for well over a centurybut the 1970s added a new wrinkle: women with pre-school-age children started to work. In earlier years, mothers had worked less than childless women. Their labor force participation had increased over time, but at the same gradual rate that other women's work rate increased. After the mid 1970s, mothers' employment increased faster than it had for childless women. Married mothers are now more likely to work than are either childless married women, or unmarried women (Cohany and Sok 2007).

Married women's employment may have inched up in the 1960s for social reasons, as secondwave feminism inspired them to seek their own careers (Collins 2009). Feminism had little to do with women's mass migration to the workplace in subsequent decades: stagnant male wages meant it increasingly took two wages to make do when one would have previously sufficed. And therein lies another reason why divorce rates continued to skyrocket throughout the 1970s.

Two theories are usually offered to explain why women's entrance en masse to the workforce drove up divorce rates. First, did work offer some women the newfound financial means to leave their husbands? Certainly this applies to some divorces, although it does raise a logical question: if earning potential obviates the need for a spouse, why did women with good jobs get married in the first place? What's more, by the dawn of the twenty-first century a higher education - and its potential for remunerative employment - had become a valued commodity for single women aspiring to marriage (Sweeney 2002). This hadn't been the case in bygone decades.

The second explanation is that women's employment created conflict at home over domestic labor and traditional gender roles. The data indeed favor this explanation in a direct test against the economic independence theory in a test conducted by the sociologist Hiromi Ono (Ono 1998). Past a certain fairly low earning threshold, divorce became more likely as a wife's earnings rose. However, earning potential - the education and work experience that might allow a divorcée to thrive on her own - did not in itself increases the odds of divorce. Ono's finding offers insight into how women's mass migration to the workplace increased divorce rates. Women with higher incomes generally work more hours and have more compelling careers. It's easy to see how this might conflict with the expectations of more traditional men.

Women entering the workplace in large numbers had one other positive effect on the divorce rate. Sociologists Scott South and Kim Lloyd (1995) have shown that divorce rates are higher in areas with more single people (in other words, areas with more alternatives to your current spouse). This dynamic extends to employment: workplaces with more opposite-sex coworkers have higher divorce rates (McKinnish 2007; Uggla and Andersson 2018).

The 1965-1980 Divorce Boom was unprecedented. So too was what came after: the longest sustained decline in the divorce rate in recorded history. Divorce remains common by historical standards, but is substantially lower than its 1980 one-out-of-two heights. What happened? One early study pointed to the rising age at marriage, and that's surely part of the answer (Heaton 
2002). But not all: the decline would have occurred even had marriage age remained constant (Goldstein 1999).

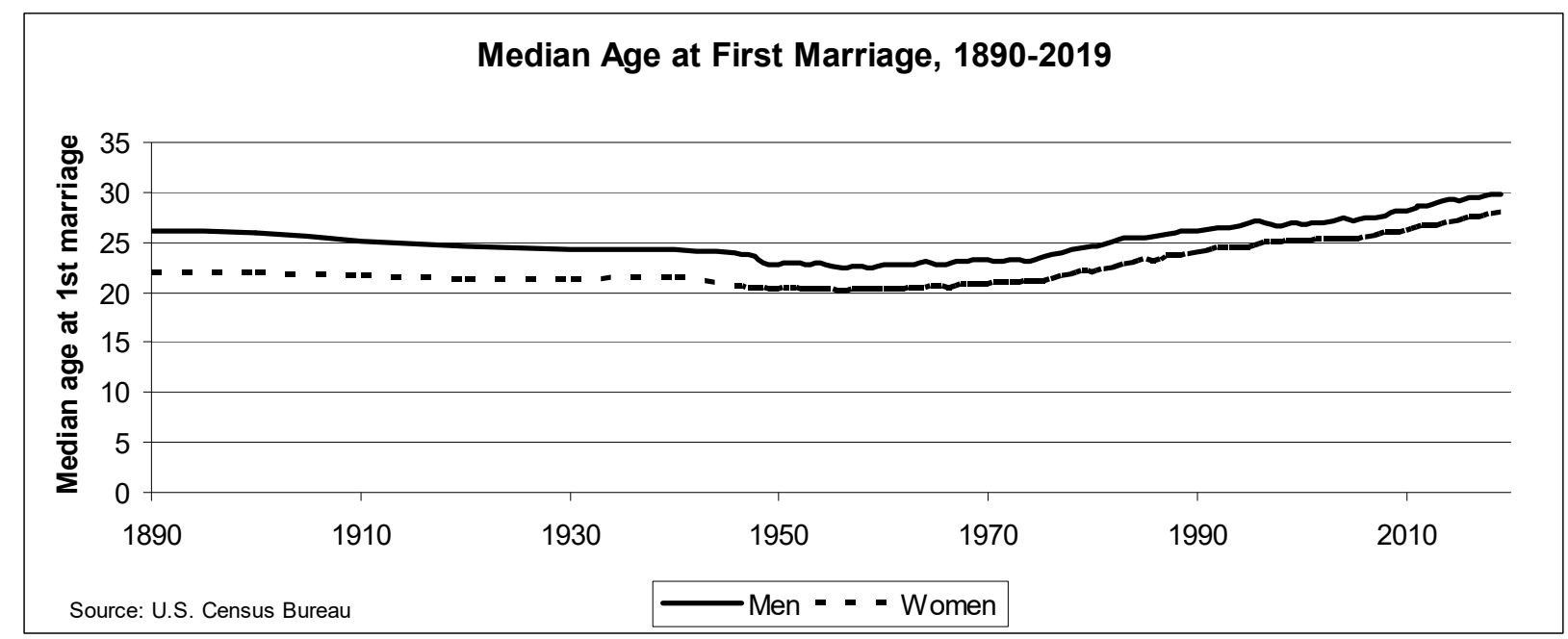

Perhaps the most significant reason for the decline in divorce concerns the changing attributes of the people getting married in the first place. Into the 1970s there was little difference in lifetime marriage rates by social class. The vast majority of Americans got married, irrespective of whether they had four-year college degrees (the marriage rate for college graduates in the 1970s is artificially suppressed by the fact that they tended to marry after finishing school, and therefore a bit later than their contemporaries who didn't complete four-year degrees).

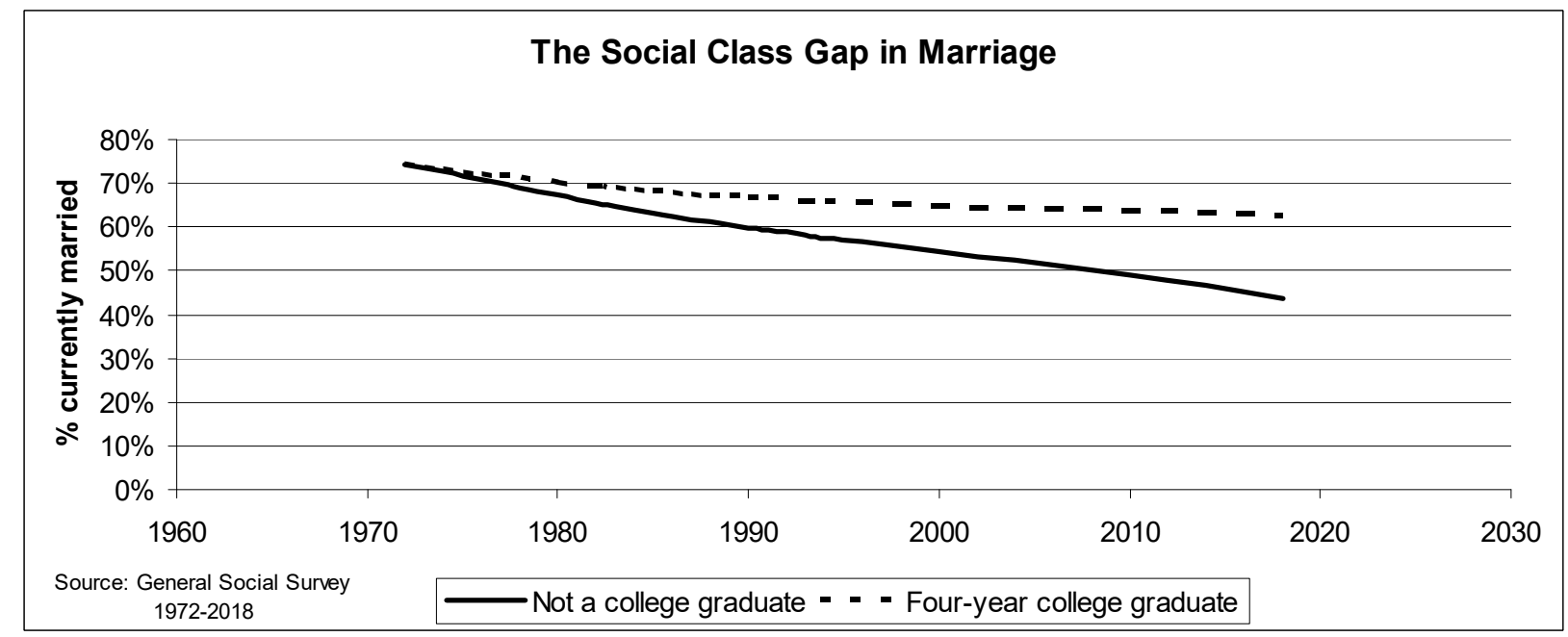

No longer: marriage has become the domain of the college-educated, who have much lower divorce rates. College grads marry at close to the same rate they always have, but those without four-year degrees have married steadily less over time. By 2018, 44 percent of Americans without college degrees were currently married, compared to 61 percent of those with degrees. If you're a college graduate, you're likely to get married and stay married; if you're not a college grad, you're less likely to get married in the first place, and more likely to get divorced if you do. 
Like the Divorce Boom, the decline of marriage in working-class America has its roots in 1960sera social changes and the long march to income inequality beginning in the 1970s. However, the trend in marriage must be evaluated together with another startling demographic transformation: the explosion of non-marital fertility.

When Daniel Patrick Moynihan, then Assistant Secretary of Labor in the Johnson Administration, published his famous (or infamous, depending on your perspective) report The Negro Family: The Case for National Action (Moynihan 1965), 7.7 percent of American births occurred outside the bonds of matrimony (for African Americans, the focus of the report, the figure was 25 percent) (Solomon-Fears 2014). For the past ten years, it's stood at about 40 percent. Nonmarital birthrates have recently plateaued and even declined a bit, most likely because of more effective and more widely available contraception (Schneider and Gemmill 2016).

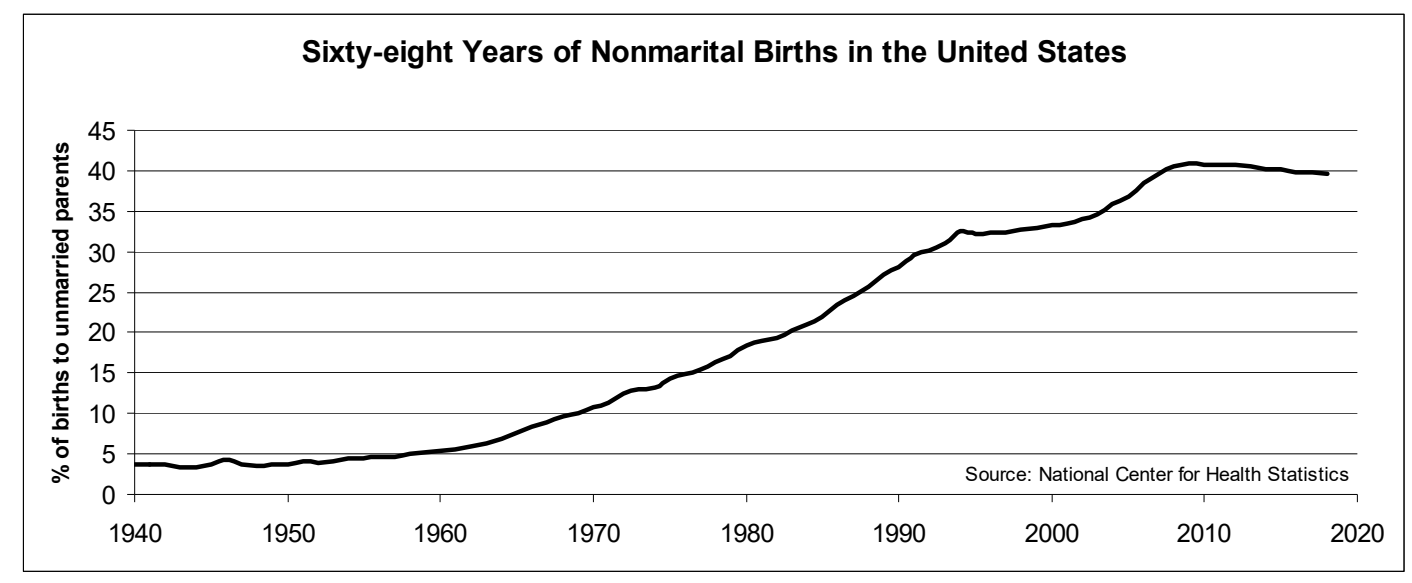

How did this happen? The most compelling explanation comes from the powerhouse economics couple of Janet Yellen and George Akerlof (respectively, former head of the Federal Reserve and Nobel Laureate): effective birth control and ready access to abortion killed the shotgun marriage. Once upon a time in America, when a man got a woman "in a family way," he almost always "did the right thing" and married her, shotgun or no shotgun (Akerlof and Yellen 1996). Birth control and abortion killed off that covenant.

Prior to the 1960s, sex out of wedlock wasn't uncommon, but the expectation of marriage always provided a backstop in case of pregnancy. The stigma of nonmarital childbirth was too great for women to contemplate sex without the promise of marriage (recall the archaic practice of a pregnant teenager being "sent away" to preserve her family's reputation in the community). And historically the potential cost was greater still, as pregnancy in the absence of modern medicine was literally life-threatening (indeed, the rate of maternal mortality has increased in the United States in the past 25 years [Villarosa 2018]).

Reproductive technology effectively decoupled sex from marriage. Women could now hook up without risking an unwanted pregnancy or an unwanted marriage. Men no longer felt the need to marry a woman when a pregnancy resulted from all that hooking up. The result was the end of the shotgun marriage. Premarital sex produced premarital pregnancies just as it always had, but 
without the compunction to get married. Consequently the rate of nonmarital fertility started to climb in the 1960s. As it did, the feedback loop between behavior and attitudes kicked in: people became more accepting of unwed mothers (Thornton and Young-DeMarco 2001), which presumably increased the number of women choosing to carry nonmarital pregnancies to term. Some conservative scholars have gone further, suggesting that the prospect of non-generative sex compelled women's participation in unwanted sexual liaisons, which in turn further boosted the rate of nonmarital childbirth (Caldwell 2020; Regnerus 2017). Doubtless this dynamic functioned at the margins, but the evidence ultimately doesn't support it. The compelled-sex theory pays little heed to women's bargaining power in the sexual contract, which has increased considerably since the 1960s as their educational attainment and earning power increased (England 2018).

The economic transformation that began in the 1970s contributed to the declining marriage rate and the consequent rise in out-of-wedlock childbearing (Wilson 2012 [1987]). But money, as we have seen, wasn't the most important explanation (Mare and Winship 1991; see also Wilcox and Wolfinger 2016; Wilcox, Wolfinger, and Stokes 2015; Lichter et al. 1991). The favored narrative among conservatives - that generous welfare benefits undercut marriage by propping up single mothers (Murray 2008 [1984]) — holds even less weight. Government transfers were declining in the 1970s and 1980s, the same years when nonmarital fertility was rising the most quickly (Ellwood and Summers 1985). When studies do show effects of welfare policy, those effects tend to be small. Irwin Garfinkel and his colleagues, for instance, showed that declining welfare between 1980 and 1996 produced at best a 6 percent decrease in the number of nonmarital births (Garfinkel et al. 2003). A detailed review by economist Robert Moffitt (1992) arrived at a similar conclusion, as did a more recent study by Mark Rosenzweig (1999).

\section{The State of the $21^{\text {st }}$ Century Family}

The foregoing pages describe what happened to the family since the mid 1960s. Where do things now stand?

Americans will spend less of their adult lives married than they did prior to the Divorce Boom. Back in 1972, just a few years into the Boom, almost three out of four American adults were married. By 2018, that number had dipped below half for the first time ever. Indeed, there has been more or less continuous decline since 1980, when the divorce rate peaked. Americans are marrying later than ever before, and divorce rates remain well above the historical average.

This much is clear. It's harder to know what percentage of Americans will ultimately marry in their lifetimes. The last authoritative estimate was produced by the demographer Joshua Goldstein almost twenty years ago. He and his coauthor concluded that almost 90 percent of adults would ultimately tie the knot (Goldstein and Kenney 2001). Since then, the crude marriage rate has continued to decline. More recent forecasts of marriage rate are much lower, all the way down to 65 percent, but are not as statistically sound as Goldstein's estimates (Martin et al. 2014). Perhaps the best back-of-the-napkin estimate starts with Goldstein and acknowledges the ongoing secular decline in marriage. The national advent of marriage equality in 2015 seems not to have affected the broader trend, probably because only about 2 percent of Americans identify as gay, lesbian, or bisexual (Gates 2011). 
Yet marriage remains a central part of American life. A 2013 Gallup poll found that 78 percent of Americans want to get married (Gallup Poll: Marriage 2013). Another survey found that only 14 percent of never-married adults hold no interest in getting married (Parker and Stepler 2017). Majorities of Americans believe marriage makes society better off, is needed in order to create strong families, and improves the financial lot of parents and children alike (Karpowitz and Pope 2018). Perhaps the ideal of marriage has taken a hit since the 1960s, but the data show little evidence of a steady decline in its popularity (Thornton and Young-DeMarco 2001).

Most young adults don't want to get married right away. Fifty years ago, Americans generally married around the time they finished school, be it high school or college. It was a step in the march to adulthood. Nowadays, marriage has been reborn as a relational capstone of sorts that signifies that a couple is "set," both financially and emotionally, at a certain level of middle-class comfort and security (Cherlin 2009; Edin and Kefalas 2005). Marriage has changed from an essential step on the road to the American dream to being a sign that a couple has finally attained the American dream.

The experience of marriage has also changed over the years. Marital happiness declined from the 1970s into the 1990s as couples grappled with the social and economic upheavals described in this chapter, but then stabilized and has even increased a bit in recent decades. A voluminous and unruly scholarly literature has debated whether, broadly, tradition or modernity provides the superior basis for conjugal bliss (e.g. Wilcox and Nock 2006; Carlson et al. 2016). Little consensus has emerged, aside from common sense: a blend of the old and the new is the basis for a happy and lasting union. To be sure, expressive individualism is now reflected in marital dynamics. Irrespective of how happy spouses are, they now lead more individual lives within marriage (Amato et al. 2007). Traditionalists might decry the modern marriage as an abdication of its greater social functions, but this view ignores the good news: marriage is malleable, capable of adapting to prevailing conditions. It's for this reason that the rumors of marriage's death are greatly exaggerated. 


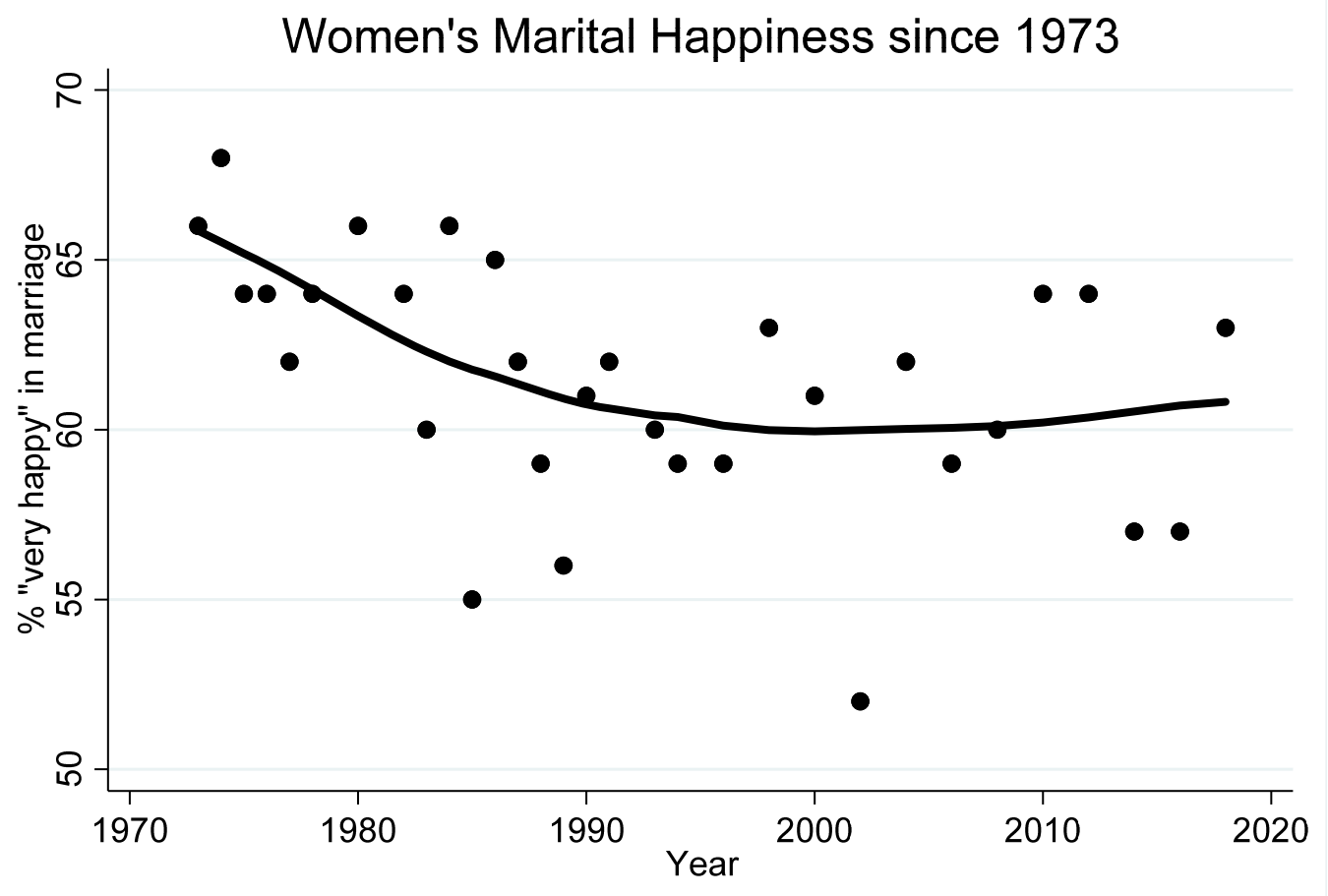

Source: General Social Survey 1972-1918

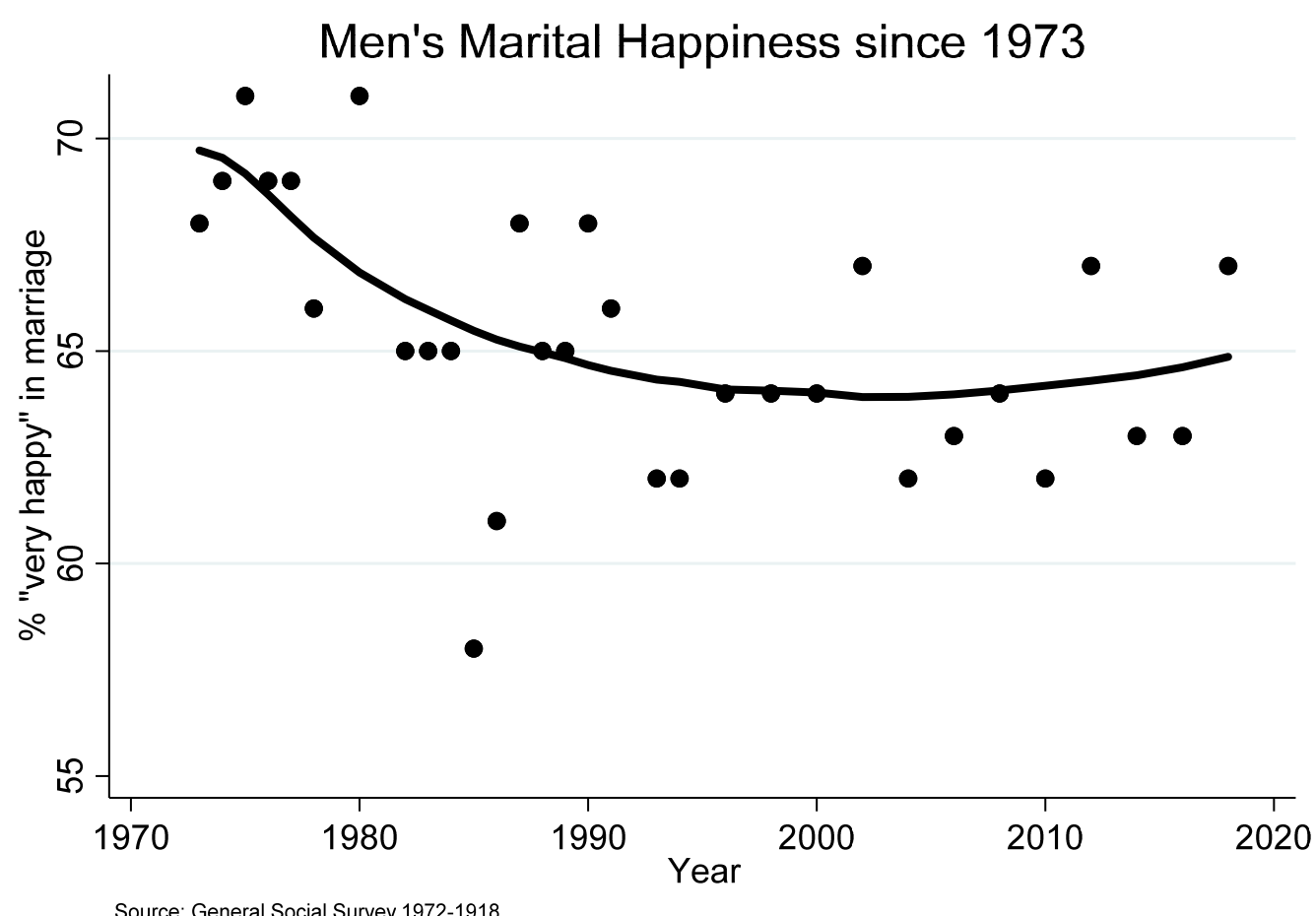

For most Americans with four-year college degrees, childbearing only commences after the capstone of marriage has been attained. For Americans without college degrees, it begins much sooner. As we have seen, nonmarital childbearing soared in America because shotgun marriages 
became less common, not because of a huge jump in premarital fertility. Why do many Americans continue to place parenthood before matrimony?

The most convincing account has come from sociologists Kathryn Edin and Maria Kefalas (2005). Over time, marriage became a luxury good of sorts for the poor. To be sure, it remains the ideal: Irrespective of income, the vast majority of Americans continue to aspire to marriage. For the less fortunate, the ideal seems unattainable under the capstone model. Stagnating male wages and unpredictable employment fail to provide adequate economic foundations for marriage. For a few, rising female wages obviate the need for marriage, and sometimes provokes discord in relationships that undermines the prospects for marriage. The ideal of the male wage earner dies hard, and some prosperous women deem their low-earning boyfriends not marriage material simply because they earn less (Wilcox and Wolfinger 2016).

This is by no means the only example of how cultural expectations work hand in hand with economic realities to depress marriage rates. Trust in prospective partners gets undermined in impoverished communities by infidelity, multi-partner fertility and the ensuing "baby mama drama," and mass incarceration. Marriage can come to seem like an unattainable dream under these circumstances, so why wait to have children? Parenthood remains an attainable dream, and an important sense of fulfillment for Americans who have dim hopes for their other prospects, be they financial, occupational, educational, or marital. Given the vanishing stigma against unwed motherhood, underprivileged Americans have good incentive to become parents before they become spouses. In turn, premarital parenthood itself reduces the odds of marriage, at least for the time being (Lichter and Graefe 2001; Lichter et al. 2003; Upchurch et al. 2001; Wilcox and Wolfinger 2007).

Nonmarital childbearing doesn't always mean single motherhood. About 60 percent of unwed mothers are living with their partners at the time of childbirth (Sassler and Lichter 2020), a number that's notably higher than it was just a few years ago (Livingston 2018). This figure represents a sea change in nonmarital cohabitation over the past 60 years, from "living in sin" to something that precedes two-thirds of all marriages (Manning 2015). As scholars have realized since the 1980s, it no longer makes sense to evaluate the American family landscape without taking cohabitation into account.

This has kept academics busy (see Sassler and Lichter 2020 for a review). Cohabitation is difficult to get a handle on because it's really many different kinds of relationships. It's the most common family structure for children born out of wedlock. It's now the default precursor to marriage. It's a trial marriage. It's a substitute for marriage. It's integral to any evaluation of stepfamilies in contemporary America (Bumpass et al. 1995). It's a way to save money. In some cases it's not even clear-cut who's cohabiting and who's not (Manning and Smock 2005; S. Brown and Manning 2009). To top it off, it's the main way in which American family demography looks different than it does in many European countries: particularly in Northern Europe, large numbers of children are born out of wedlock to stable cohabiting parents (PerelliHarris 2014; Wilcox and DeRose 2017). That's usually not the case in the United States, where most live-in relationships don't last long (Musick and Michelmore 2018). 
A full review of these trends is beyond the scope of this chapter, so we will suffice with two broad observations. First, we shouldn't look too hard to explain the remarkable rise of cohabitation - it was an inevitable outgrowth of the other social forces described in this chapter. Effective birth control and the deterioration of traditional social penalties associated with premarital sex made it to be expected that some couples would seek the escalation of dating by other means. At the same time, the headwinds against marriage - economic insecurity, and the expectations of the capstone model-ensured that other couples would move in together but stop short of tying the knot. Finally, the Divorce Boom made it more likely that some couples would hesitate before jumping in feet first to marriage, especially if they'd already been married in the past or had divorced parents (Wolfinger 2005). All of this made the rise of cohabitation inevitable.

Second, we should resist thinking of cohabitation as a substitute for marriage, even though it often resembles marriage in various ways. Thirty years ago, social scientists observed that declines in the marriage rate were fully offset by rises in the level of nonmarital cohabitation, leading to speculation that cohabitation might be emerging as a replacement for marriage (Bumpass et al. 1991). It isn't, at least not for most people. Ten years down the road, just 6 percent of cohabiting couples are still living together outside the bonds of matrimony (Mernitz 2018). Thus the number of people in long-term cohabiting relationships is vanishingly small, and often seems limited to the participation of academics who say things like, "We don't believe in the bourgeois institution of marriage" even as they do their best to structure their relationships exactly like a bourgeois marriage.

The broader point here is that cohabitation can be many different kinds of relationships. Some are distinctly more marriage-like than others. To be sure, many cohabiters are in relationships that can't be thought of as anything other than families. They're raising children together, making homes and lives together, and sharing the division of all the labor this entails. At the same time, cohabiting relationships consistently score lower on all metrics of relationship quality (Wilcox and Wolfinger 2016). The exception is couples who move in with firm intentions of marriage (S. Brown and Booth 1996; Stanley et al. 2010).

\section{Radical Pronouncements about the Modern Family Are Wrong}

As I was completing this chapter, one of America's most prominent public intellectuals offered a radical assessment of the contemporary family. David Brooks, the center-right New York Times columnist and NPR commentator, published a long article in The Atlantic arguing that the nuclear family was ahistorical, an aberration that had become an unrealized and outmoded ideal (Brooks 2020). Instead, we should be looking toward extended families, and the social networks that scholars call "created kinship."

What made Brooks' polemic especially startling is the fact that the moderate conservative intelligentsia - perhaps best represented by Brooks' New York Times colleague Ross Douthathas long comprised the strongest advocates for marriage in contemporary America. Brooks' manifesto quickly produced a broad roster of critics that included many of our foremost students of the family, including sociologists Andrew Cherlin (2020) and W. Bradford Wilcox (2020), Richard Reeves (2020) of the Brookings Institute, and others. 
Cherlin's take was most on the money:

Still, Brooks is right to recognize that nuclear families today work best for adults who can find stable employment at decent wages - a shrinking group that includes most collegeeducated people but a decreasing proportion of those without college educations. And he is correct to note that the cultural tide of individualism has eroded the formation and maintenance of life-long marital ties. He is to be commended for arguing to conservatively-minded observers that a large-scale return to the nuclear family is unlikely except among the privileged, while also maintaining that the alternative families defended by liberals have worked out poorly for the unprivileged.

Were things bound to turn this way? I'd argue that the answer is yes.

It's hard to dislodge 1950s nostalgia from the popular imagination. Liberals look fondly at an era of high unionization, low income inequality, and a surfeit of good-paying jobs that didn't require higher education. Conservatives in turn venerate the 1950s family: early and plentiful marriage with lots of kids, but low divorce rates. Everyone wants to know why we can't have some version of this idyll back again. After all, it would just take a decade of ruinous worldwide depression, followed immediately by the most lethal war in human history. Both were required to create the economic and demographic conditions that produced the anomalous 1950s family.

Nineteen-fifties nostalgia also tends to elide the losers. African Americans and other minorities were deprived of their constitutional rights and consigned to second-class citizenship. Many women were content as housewives, but they had little say in the matter given prevailing norms and their lack of legal rights (into the 1970s women were not guaranteed the right to own property or have credit cards on their own [Collins 2009]). The persecution of gays and lesbians hit its modern nadir in the United States, Great Britain, and other countries in the 1950s (Robb 2004). The civil rights movements finally started to put these injustices right. In retrospect, it's hard to see how the American family wouldn't be roiled in the process, especially given the other social and economic disruptions of the 1960s and 1970s. This includes the advent of modern birth control, which in itself remedied an even older inequity.

Childrearing has always been uniquely fraught for women. Until fairly recently, it posed mortal peril. As late as the 1930s, more than one in two hundred American women died in childbirth (Singh 2010). The United States continues to have a maternal mortality rate several times as high as other countries in the developed world (Martin and Montagne 2017). Maternal mortality has plummeted since the Great Depression, here and abroad, but the historical memory persists. What hasn't changed is the responsibility of carrying a child to term, and the care a newborn requires. So long as chastity was the only way a woman could control her own fertility, she couldn't be an equal citizen. Her ability to pursue an education, develop a career, or run for elective office was compromised. Birth control was essential for full citizenship, a just society, and an economy that made optimal use of its human capital.

Also essential, of course, was the civil rights legislation of the 1960s and the long march to equality for women, racial and ethic minorities, and LGBT Americans. America couldn't live up 
to her founding ideals without equal rights, full civic participation, and economic opportunity for all. The family was bound to change in the process, especially given the economic transformation that began in the 1970s. As Andrew Cherlin (2020) suggests, a modicum of acceptance would benefit public discourse going forward. This is an appeal to our values, not an abdication of them.

This acceptance should be tempered by what social science tells us about the family. Conservatives should acknowledge that the modern welfare state didn't cause the retreat from marriage. Liberals should accept that children do best in two-parent families, gay or straight, and shouldn't hesitate to say so. A vast scholarly literature has incontrovertibly demonstrated that unwed parenthood, single parenting, and divorce have adverse consequences for children (for overviews see Clarke-Stewart and Brentano 2006; McLanahan and Sandefur 1994; Wolfinger 2005). Marriage is also good for adults (Waite and Gallagher 2001), although recent studies suggest that the benefits may not be as strong as was once believed (cf. Beam et al. 2017; Dinescu et al. 2016; Horn et al. 2013; Kalmijn 2017; Killewald and Lundberg 2017; Ludwig and Brüderl 2018). Family discourse — and perhaps families themselves — would be much improved if old dogmas fell by the wayside.

\section{Social Policies to Benefit Families}

One positive step that is eminently feasible is reducing unplanned pregnancies. Since 1994, the majority of single parent families have been the product of nonmarital fertility, not divorce (Rawlings and Saluter 1995). Never-married mothers have consistently lower incomes than do divorced mothers (McKeever and Wolfinger 2011, 2012) and produce comparably adverse environments for offspring (McLanahan and Sandefur 1994). The vast majority of unmarried pregnancies are unplanned (Finer and Zolna 2016), so expanding access to effective contraception would go a long way to turn "drifters" into "planners," who delayed pregnancy until better prepared to care for children (Sawhill 2014).

Expanded access to contraception is an easy fix, relatively inexpensive and opposed principally by a waning rearguard of religious conservatives. The harder choices come with policy responses to the influx of women into the paid labor force, including by single mothers. Western nations have adopted a variety of responses to the problems posed by working parents that broadly boil down to two choices: encouraging a parent to stay home, or promoting female labor force participation by underwriting the cost of childcare (Morgan 2006). Prior to the 1996 welfare reform act, federal policy in the United States effectively encouraged single mothers to stay out of the paid labor force (Edin and Lein 1997). Since 1996, the United States, virtually alone among developed nations, has chosen neither path to address the influx of women into the labor market. It is therefore not surprising that federal programs for pre-school-age children, both paid parental leave and federally subsidized childcare, have been featured issues in the 2020 presidential campaign.

President George W. Bush promised spending over a billion dollars to promote marriage (Kowaleski-Jones and Wolfinger 2005), an effort that came to naught as the marriage rate continued to decline. Nonetheless, the federal government should ensure that it doesn't 
discourage marriage, by eliminating marriage penalties in the tax code, and doubling the income thresholds in means-tested programs so that people don't lose their benefits if they tie the knot.

Richard Nixon famously floated the idea of a "negative income tax," functionally a basic income subsidy that would provide all Americans with a minimum income of about $\$ 15,000$ in today's dollars (Anderson 2020). His proposal went nowhere, and for decades it vanished from the national agenda. It's now back in force, with a spate of recent books and articles (e.g., Lowrey 2018) , the 2020 single-issue presidential candidacy of Democrat Andrew Yang, and even its own peer-reviewed journal, Basic Income Studies. More politically feasible (and more affordable) would be a universal basic income for children. In 2019 Senators Michael Bennet (DColorado) and Mitt Romney (R-Utah) unveiled bipartisan legislation to provide such subsidies.

Short of direct cash transfers, there has long been bipartisan support for what Ronald Reagan called America's most effective anti-poverty program, the earned income tax credit. A beefed-up EITC would benefit tens of millions of American families, as would a larger child tax credit. Both programs incentivize employment, ultimately a desirable objective. The downside is the families who fall through the gaps: childless adults, and families headed by unemployed adults. In the best of worlds the safety net would be expanded to benefit these Americans. 


\section{REFERENCES}

Aberg, Y. 2009. The Contagiousness of Divorce. The Oxford Handbook of Analytical Sociology, $342-364$.

Akerlof, G., and Yellen, J.L. 1996. An Analysis of Out-of-Wedlock Births in the United States. Brookings Institute. https://www.brookings.edu/research/an-analysis-of-out-of-wedlockbirths-in-the-united-states/

Akers, D.S. 1967. On Measuring the Marriage Squeeze. Demography 4 (No. 2): 907-924.

Amato, P.R., Booth, A., Johnson, D.R., and Rogers, S.J. 2007. Alone Together: How Marriage in America Is Changing. Harvard University Press.

Amato, Paul R., Laura Spencer Loomis, and Alan Booth. 1995. Parental Divorce, Marital Conflict, and Offspring Well-being during Early Adulthood. Social Forces 73 (No. 3): $895-915$.

Andersen, K. 2017. Fantasyland: How America Went Haywire: A 500-Year History. New York: Random House Publishing Group.

. 2020. Evil Geniuses: The Unmaking of America: a Recent History. New York: Random House Publishing Group.

Beam, C.R., Dinescu, D., Emery, R., and Turkheimer, E. 2012. A Twin Study on Perceived Stress, Depressive Symptoms, and Marriage. Journal of Health and Social Behavior 58 (No.1): 37-53

Brooks, D. 2020. The Nuclear Family was a Mistake. The Atlantic (March 2020). https://www.theatlantic.com/magazine/archive/2020/03/the-nuclear-family-was-a$\underline{\text { mistake/605536/ }}$

Brown, T.S. 2013. West Germany and the Global Sixties: The Anti-Authoritarian Revolt, 19621978. New York: Cambridge University Press.

.2014. 1968 in West Germany: The Anti-Authoritarian Revolt. The Sixties 7 (No. 2): 99-116.

Brown, S.L., and Booth, A. 1996. Cohabitation Versus Marriage: A Comparison of Relationship Quality. Journal of Marriage and the Family. 58 (No. 3): 668-678.

Brown, S.L., and Manning, W.D. 2009. Family Boundary Ambiguity and the Measurement of Family Structure: The Significance of Cohabitation. Demography 46 (No.1): 85-101.

Bumpass, L.I., Raley, R.K., and Sweet, J.A. 1995. The Changing Character of Stepfamilies: Implications of Cohabitation and Nonmarital Childbearing. Demography 32 (No. 3): 425436. 
Bumpass, L.I., Sweet, J.A., and Cherlin, A.J. 1991. The Role of Cohabitation in Declining Rates of Marriage. Journal of Marriage and the Family 53 (No. 4): 913-927.

Caldwell, C. 2020. The Age of Entitlement: America Since the Sixties. Simon \& Schuster.

Carlson, D.L., Hanson, S., and Fitzroy, A. 2016. The Division of Child Care, Sexual Intimacy, and Relationship Quality in Couples. Gender \& Society 30 (No. 3): 442-466.

Centers for Disease Control and Prevention / National Center for Health Statistics. 2003. https://www.cdc.gov/nchs/data/statab/natfinal2003.annvol1_01.pdf

Cherlin, A.J. 2009. The Marriage-Go-Round: The State of Marriage and the Family in America Today. New York: Vintage.

2020. David Brooks Is Urging Us To Go Forward, Not Backward. The Family Studies Blog. (February 12, 2020.) https://ifstudies.org/blog/david-brooks-is-urging-us-to-goforward-not-backward

Clarke-Stewart, A., and Brentano, C. 2006. Divorce: Causes and Consequences. Yale University Press.

Cohany, S.R., and Sok, E. 2007. Trends in Labor Force Participation of Married Mothers of Infants. Monthly Labor Review. (February 2007): 9-16. https://www.bls.gov/opub/mlr/2007/02/art2full.pdf

Collins, G. 2009. When Everything Changed: The Amazing Journey of American Women from 1960 to the Present. New York: Little, Brown.

Desilver, D. 2018. For Most U.S. Workers, Real Wages Have Barely Budged in Decades. Fact Tank, Pew Research Center. (August 7, 2018.) https://www.pewresearch.org/facttank/2018/08/07/for-most-us-workers-real-wages-have-barely-budged-for-decades/

Dinescu, D., Turkheimer, E., Beam, C.R., Horn, E.E., Duncan, G., and Emery, R.E. 2016. Is Marriage a Buzzkill? A Twin Study of Marital Status and Alcohol Consumption. Journal of Family Psychology, 30 (No. 6): 698-707.

Donovan, S.A., and Bradley, D.H. 2019. Real Wage Trends, 1979 to 2018. Congressional Research Service. (July 23, 2019.) https://fas.org/sgp/crs/misc/R45090.pdf

Edin, K., and Kefalas, M. 2005. Promises I Can Keep: Why Poor Women Put Motherhood Before Marriage. University of California Press.

Edin, K. and Lein, L. 1997. Making Ends Meet: How Single Mothers Survive Welfare and LowWage Work. Russell Sage Foundation. 
Ellwood, D.T., and Summers, L.H. 1985. Poverty in America: Is Welfare the Answer or the Problem? National Bureau of Economic Research, Working Paper No. 1711.

England, P. 2018. Book Review: Cheap Sex: The Transformation of Men, Marriage, and Monogamy. Men and Masculinities. 21 (No.1): 252-154.

Frum, D. 2008. How We Got Here: The 70's: The Decade that Brought You Modern Life (for Better or Worse). Basic Books.

Finer, L. B., and Zolna, M. R. (2016). Declines in Unintended Pregnancy in the United States, 2008-2011. New England Journal of Medicine. 374 (No. 9): 843-852.

Gallup Poll: Marriage. 2019. https://news.gallup.com/poll/117328/Marriage.aspx

Gates, G.J. 2011. How Many People Are Lesbian, Gay, Bisexual andTtransgender? The Williams Institute, UCLA School of Law (April 2011). https://williamsinstitute.law.ucla.edu/wpcontent/uploads/Gates-How-Many-People-LGBT-Apr-2011.pdf

Garfinkel, I., Huang, C-C., McLanahan, S.S., and Gaylin, D.S. 2003. The Roles of Child Support Enforcement and Welfare in Non-Marital Childbearing. Journal of Population Economics. 16 (No. 1): 55-70.

Glenn, N.D. 1997. A Reconsideration of the Effect of No-Fault Divorce on Divorce Rates. Journal of Marriage and the Family. 59 (No. 4): 1026-1030

Goldstein, J.R. 1999. The Leveling of Divorce in the United States. Demography 36 (No. 3): 409-414.

Goldstein, J.R., and Kenney, C.T. 2001. Marriage Delayed or Marriage Forgone? New Cohort Forecasts of First Marriage for U.S. Women. American Sociological Review 66 (No. 4): 506-519.

Gruber, J. 2004. Is Making Divorce Easier Bad for Children? The Long-Run Implications of Unilateral Divorce. Journal of Labor Economics 22 (No. 4): 799-833.

Heaton, T.B. 2002. Factors Contributing to Increasing Marital Stability in the United States. Journal of Family Issues 23 (No. 3):392-409.

Horn, E.E., Xu, Y., Beam, C.R., Turkheimer, E., Emery, R.E. 2013. Accounting for the Physical and Mental Health Benefits of Entry into Marriage: A Genetically Informed Study of Selection and Causation. Journal of Family Psychology 27 (No. 1): 30-41.

Jekielek, Susan M. 1998. Parental Conflict, Marital Disruption, and Children's Emotional WellBeing. Social Forces 76 (No. 3): 905-936.

Kalmijn, M. 2017. The Ambiguous Link Between Marriage and Health: A Dynamic Reanalysis of Loss and Gain Effects. Social Forces 95 (No. 4): 1607-1636. 
Karpowitz, C.F., and Pope, J.C. 2018. The American Family Survey. https://media.deseret.com/media/misc/pdf/afs/2018-AFS-Final-Report.pdf

Killewald, A., Lundberg, I. 2017. New Evidence Against a Causal Marriage Wage Premium. Demography 54 (No. 3): 1007-1028.

Kowaleski-Jones, L., and Wolfinger, N.H. 2005. Fragile Families and the Marriage Agenda. Springer, New York.

Lasch, C. 1979. Culture of Narcissism: American Life in an Age of Diminishing Expectations. Norton.

Lichter, D.T., and Graefe, D.R. 2001. Finding a Mate? The Marital and Cohabitation Histories of Unwed Mothers. In: Wu, L,.L., Wolfe, B. (Eds.), Out of Wedlock, 317-343. Russell Sage, New York.

Lichter, D., Graefe, D.R., and Brown, J.B. 2003. Is Marriage a Panacea? Union Formation Among Economically Disadvantaged Unwed Mothers. Social Problems 50 (No. 1): 6086.

Lichter, D.T., McLaughlin, D.K., Kephart, G., and Landry, D. 1992. Race and the Retreat from Marriage: A Shortage of Marriageable Men? American Sociological Review 57 (No. 6): 781-799.

Lilla, M. 2018. The Once and Future Liberal: After Identity Politics. New York: Harper.

Livingston, G. 2018. The Changing Profile of Unmarried Parents. Pew Research Center (April 2018). https://www.pewsocialtrends.org/wp-content/uploads/sites/3/2018/04/UnmarriedParents-Full-Report-PDF.pdf

Lowrey, A. 2018. Give People Money: How a Universal Basic Income Would End Poverty, Revolutionize Work, and Remake the World. New York: Broadway books.

Ludwig, V., and Brüderl, J. 2018. Is There a Male Marital Wage Premium? New Evidence from the United States. American Sociological Review 83 (No. 4): 744-770.

Manning, W.D. 2015. Cohabitation and Child Wellbeing. The Future of Children 25 (No. 2): 5166.

Manning, W.D., and Smock, P.J. 2005. Measuring and Modeling Cohabitation: New Perspectives from Qualitative Data. Journal of Marriage and the Family 67 (No. 4): 9891002.

Mare, R.D., and Winship, C. 1991. Socioeconomic Change and the Decline of Marriage for Blacks and Whites. The Urban Underclass 175: 175-201. 
Martin, N., and Montagne, R. 2017. U.S. Has the Worst Rate of Maternal Deaths in the Developed World. NPR Series, Lost Mothers: Maternal Mortality In The U.S. (May 12, 2017.) https://www.npr.org/2017/05/12/528098789/u-s-has-the-worst-rate-of-maternaldeaths-in-the-developed-world

Martin, S.P., Astone, N.M., and Peters, H.E. 2014. Fewer Marriages, More Divergence: Marriage Projections for Millennials to Age 40. Urban Institute (April 29, 2014). https://www.urban.org/sites/default/files/publication/22586/413110-Fewer-MarriagesMore-Divergence-Marriage-Projections-for-Millennials-to-Age-.PDF

McDermott, R., Fowler, J.H., and Christakis, N.A. 2013. Breaking Up Is Hard to Do, Unless Everyone Else Is Doing It Too: Social Network Effects on Divorce in a Longitudinal Sample. Social Forces 92 (No. 2): 491-519.

McKeever, M., and Wolfinger, N.H. 2011. Thanks for Nothing: Income and Labor Force Participation for Never-Married Mothers since 1982. Social Science Research 40 (No. 1): 63-76.

. 2012. Over the Long Haul: The Persistent Economic Consequences of Single Motherhood. In: Blair, S.L. (Ed.), Economic Stress and the Family, 1-39. Emerald Publishing, Bingley, UK.

McKinnish, T.G. 2007. Sexually Integrated Workplaces and Divorce Another Form of On-theJob Search. Journal of Human Resources 42 (No. 2): 331-352.

McLanahan, S., and Sandefur, G. 1994. Growing Up with a Single Parent. What Hurts, What Helps. Harvard University Press.

Mernitz, S.E. 2018. A Cohort Comparison of Trends in First Cohabitation Duration in the United States. Demographic Research 38 (No. 66): 2073-2086.

Moffitt, R. 1992. Incentive Effects of the U.S. Welfare System: A Review. Journal of Economic Literature 30 (No. 1): 1-61.

Morgan, K.J. 2006. Working Mothers and the Welfare State: Religion and the Politics of WorkFamily Policies in Western Europe and the United States. Stanford University Press.

Moynihan, D.P. 1965. The Negro Family: The Case for National Action. No. 31-33. US Government Printing Office. https://www.dol.gov/general/aboutdol/history/webidmoynihan

Murray, C. 1984 [2008]. Losing Ground: American Social Policy, 1950-1980. New York: Basic Books, 1985.

Musick, K., and Michelmore, K. 2018. Cross-National Comparisons of Union Stability in Cohabiting and Married Families with Children. Demography 55 (No. 4): 1389-1421. 
The New York Times. 2020. Was Your Life Changed by a Book? (Opinion, January 9, 2020.) https://www.nytimes.com/2020/01/09/opinion/letters/books-readers.html

Ono, H. 1998. Husbands' and Wives' Resources and Marital Dissolution. Journal of Marriage and the Family 60 (No. 3): 674-689.

Parker, K., and Stepler, R. 2017. As U.S. Marriage Rate Hovers at 50\%, Education Gap in Marital Status Widens. Fact Tank, Pew Research Center (September 14, 2017). https://www.pewresearch.org/fact-tank/2017/09/14/as-u-s-marriage-rate-hovers-at-50education-gap-in-marital-status-widens/

Patterson, O. 2014. How Sociologists Made Themselves Irrelevant. Chronicle of Higher Education 61 (No. 14): B4-B5.

Pear, R. and Kirkpatrick, D.D. "Bush Plans \$1.5 Billion Drive For Promotion of Marriage." The New York Times (January 14, 2004), https://www.nytimes.com/2004/01/14/us/bushplans-1.5-billion-drive-for-promotion-of-marriage.html

Perelli-Harris, B. 2014. How Similar are Cohabiting and Married Parents? Second Conception Risks by Union Type in the United States and Across Europe. European Journal of Population 30 (No. 4): 437-464.

Pew Research Center. 2019. Public Trust in Government, 1958-2019. (April 11, 2019). https://www.people-press.org/2019/04/11/public-trust-in-government-1958-2019/

Phillips, R. 1988. Putting Asunder: A History of Divorce in Western Society. New York: Cambridge University Press. Press.

. Untying the Knot: A Short History of Divorce. New York: Cambridge University

Pryor, J.H., Hurtado, S., Saenz, V.B., Santos, J., and Korn, W.S. 2007. The American Freshman: Forty Year Trends, figure 14. Higher Education Research Institute, UCLA. Available at https://heri.ucla.edu/PDFs/40TrendsManuscript.pdf

Putnam, R.D. 2000. Bowling Alone: The Collapse and Revival of American Community. New York: Simon \& Schuster.

Rawlings, S.W., and Saluter A.F. 1995. Household and Family Characteristics: March 1994. U.S. Bureau of the Census, Current Population Reports, P20-483, U.S. Government Printing Office, Washington, DC. Available at https://www.census.gov/prod/1/pop/p20483.pdf.

Reeves, R.V. 2020. David Brooks Is Correct: Both the Quality and Quantity of Our Relationships Matter. The Family Studies Blog (February 11, 2020). 
https://ifstudies.org/blog/david-brooks-is-correct-both-the-quality-and-quantity-of-ourrelationships-matter

Regnerus, M. 2017. Cheap Sex: The Transformation of Men, Marriage, and Monogamy. New York: Oxford University Press.

Robb, G. 2004. Strangers: Homosexual Love in the Nineteenth Century. New York: WW Norton \& Company.

Rosenzweig, M.R. 1999. Welfare, Marital Prospects, and Nonmarital Childbearing. Journal of Political Economy 107 (No. S6): S3-S32.

Sassler, S., and Lichter, D.T. 2020. Cohabitation and Marriage: Complexity and Diversity in Union-Formation Patterns. Journal of Marriage and the Family 82 (No. 1): 35-61.

Sawhill, I.V. 2014. Generation Unbound: Drifting into Sex and Parenthood without Marriage. Washington D.C., Brookings Institution Press.

Schneider, D., and Gemmill, A. 2016. The Surprising Decline in the Non-Marital Fertility Rate in the United States. Population and Development Review 42 (No. 4): 627-649.

Singh, G.H. 2010. Maternal Mortality in the United States, 1935-2007: Substantial Racial/Ethnic, Socioeconomic, and Geographic Disparities Persist. Health Resources and Services Administration / Maternal and Child Health Bureau. https://www.hrsa.gov/sites/default/files/ourstories/mchb75th/mchb75maternalmortality.p df

Solomon-Fears, C. 2014. Nonmarital Births: An Overview. Congressional Research Service. (July 30, 2014.) https://fas.org/sgp/crs/misc/R43667.pdf.

South, S.J., and Lloyd, K.M. 1995. Spousal Alternatives and Marital Dissolution. American Sociological Review 60 (No. 1): 21-35.

Stanley, S.M., Rhoades, G.K. Amato, P.R., Markman, H.J., and Johnson, C.A. 2010. The Timing of Cohabitation and Engagement: Impact on First and Second Marriages. Journal of Marriage and the Family 72 (No. 4): 906-918.

Storr, W. 2018. Selfie: How We Became So Self-Obsessed and What It's Doing to Us. New York: Abrams.

Sweeney, M.M. 2002. Two Decades of Family Change: The Shifting Economic Foundations of Marriage. American Sociological Review 67 (No. 1): 132-147.

Thornton, A., and Young-DeMarco, L. 2001. Four Decades of Trends in Attitudes Toward Family Issues in the United States: The 1960s Through the 1990s. Journal of Marriage and the Family 63 (No. 4): 1009-1037. 
Toosi, M., and Morisi, T. 2017. Women in the Workforce Before, During and After the Great Recession. U.S. Bureau of Labor Statistics, Spotlight on Statistics (July 2017). https://www.bls.gov/spotlight/2017/women-in-the-workforce-before-during-and-afterthe-great-recession/pdf/women-in-the-workforce-before-during-and-after-the-greatrecession.pdf

Turner, R.H. 1976. The Real Self: From Institution to Impulse. American Journal of Sociology 81 (No. 5): 989-1016.

Twenge, J.M., Campbell, W.K., and Freeman, E.C. 2012. Generational Differences in Young Adults' Life Goals, Concern for Others, and Civic Orientation, 1966-2009. Journal of Personality and Social Psychology 102 (No. 5): 1045-1062.

Uggla, C., and Andersson, G. 2018. Higher Divorce Risk when Mates are Plentiful? Evidence from Denmark. Biology letters 14 (No. 9): 1-4.

United States Census Bureau. 2019. Median Age at First Marriage: 1890 to Present. https://www.census.gov/content/dam/Census/library/visualizations/timeseries/demo/families-and-households/ms-2.pdf

Upchurch, D.M., Lillard, L.A., and Panis, C. W.A.. 2001. The Impact of Nonmarital Childbearing on Subsequent Marital Formation and Dissolution. In: Wu, L. L., Wolfe, B (Eds.), Out of Wedlock: Causes and Consequences of Nonmarital Fertility, 344-380. Russell Sage Foundation, New York.

Vavreck, L 2015. The Long Decline of Trust in Government, and Why That Can Be Patriotic. The New York Times (July 3, 2015). https://www.nytimes.com/2015/07/04/upshot/thelong-decline-of-trust-in-government-and-why-that-can-be-patriotic.html

Villarosa, L. 2018. Why America's Black Mothers and Babies Are in a Life-or-Death Crisis. The New York Times Magazine (April 11, 2018). https://www.nytimes.com/2018/04/11/magazine/black-mothers-babies-death-maternal$\underline{\text { mortality.html }}$

Vlosky, D.A., and Monroe, P.A. 2002. The Effective Dates of No-Fault Divorce Laws in the 50 States. Family Relations 51 (No. 4): 317-324.

Waite, L.J., and Gallagher, M. 2001. The Case for Marriage: Why Married People are Happier, Healthier and Better Off Financially. Penguin Random House.

Wernick, R. 1996. Where You Went if You Really Had to Get Unhitched. Smithsonian 27: 6472.

Wilcox, W.B., and Wang, W. 2020. What Do We Know About Extended Families in America? A Response to David Brooks. The Family Studies Blog (February 10, 2020). 
https://ifstudies.org/blog/what-do-we-know-about-extended-families-in-america-aresponse-to-david-brooks

Wilcox, W.B., and DeRose, L. 2017. In Europe, Cohabitation Is Stable... Right? Brookings Institute (March 27, 2017). https://www.brookings.edu/blog/social-mobilitymemos/2017/03/27/in-europe-cohabitation-is-stable-right/

Wilcox, W.B., and Nock, S.L. 2006. What's Love Got To Do With It? Equality, Equity, Commitment and Women's Marital Quality. Social Forces 84 (No. 3): 1321-1345;

Wilcox, W.B., and Wolfinger, N.H. 2007. Then Comes Marriage? Religion, Race, and Marriage in Urban America. Social Science Research 36 (No. 2): 569-589.

. 2016. Soul Mates: Religion, Sex, Love, and Marriage among African Americans and Latinos. Oxford University Press.

Wilcox, W.B., Wolfinger, N.H., and Stokes, C.E. 2015. One Nation, Divided: Culture, Civic Institutions, and the Marriage Divide. The Future of Children 25 (No. 2): 111-127.

Wilson, W.J. 2012 [1987]. The Truly Disadvantaged: The Inner City, the Underclass, and Public Policy. University of Chicago Press.

Wolfers, J. 2006. Did Unilateral Divorce Laws Raise Divorce Rates? A Reconciliation and New Results. American Economic Review 96 (No. 5): 1802-1820

Wolfinger, N.H. 2004. The Mixed Blessings of No-Fault Divorce. Whittier Journal of Child \& Family Advocacy 4: 407-430.

. 2005. Understanding the Divorce Cycle: The Children of Divorce in Their Own Marriages. Cambridge University Press.

.2018. Nine Decades of Promiscuity. The Family Studies Blog (February 6, 2018). https://ifstudies.org/blog/nine-decades-of-promiscuity 